\title{
PENGEMBANGAN DESAIN MODEL PEMBELAJARAN \\ BLENDED LEARNING PADA METODE NUMERIK: \\ BLENDED COOPERATIVE LEARNING
}

\section{Siti Aminah}

Sekolah Tinggi Informatika \& Komputer Indonesia (STIKI), Indonesia

Email: sitiaminah@stiki.ac.id

\begin{tabular}{l}
\hline Info Artikel \\
\hline Sejarah Artikel: \\
\begin{tabular}{l} 
Diserahkan 28 Oktober 2019 \\
Direvisi 15 Juni 2020 \\
Direvisi 24 Juli 2020 \\
Disetujui 27 Oktober 2020 \\
\hline Keywords: \\
problem based learning, \\
blended learning, \\
cooperative learning, \\
mathematic, \\
engineering
\end{tabular} \\
\hline
\end{tabular}

\section{Abstract}

This study aims to develop design of blended learning model, and then call Blended Cooperative Learning model ( $B C L)$.

This research is research development. Stages of the research use Thiagarajan, Semmel \& Semmel development model. this study limited by 3 stages. There are the define stage, the design stage, and the developing stage. This research was attended at STIKI Malang in Informatics Engineering students taking Numerical Method courses. Data collection techniques used validation sheets for the design of BCL Model and materials to two validators. Data analysis uses average scoring.

The results of this study are design of BCL model and materials. The materials are materials learning in LMS, RPP, and worksheets. The results of this study is design of blended learning Blended Cooperative Learning is feasible to use.

\begin{abstract}
Abstrak
Tujuan dari penelitian ini adalah mengembangkan desain model pembelajaran blended learning yang dinamakan Blended Cooperative Learning.

Penelitian ini merupakan penelitian pengembangan. Tahapan pada penelitian mengacu pada model pengembangan Thiagarajan. Semmel \& Semmel yang dibatasi pada 3 tahap, yaitu tahap pendefinisian, perencanaan dan pengembangan. Penelitian ini dilakukan di STIKI Malang pada mahasiswa Teknik Informatika yang menempuh mata kuliah Metode Numerik. Teknik pengumpulan data menggunakan lembar validasi untuk desain pembelajaran dan bahan-bahan ajarnya kepada dua validator. Analisa data menggunakan penskoran rata-rata.

Hasil dari penelitian ini adalah desain Blended Cooperative Learning dan bahan ajar berupa pembelajaran dalam LMS, RPP, dan worksheet. Hasil dari penelitian ini menghasilkan desain model Blended Cooperative Learning yang sudah layak digunakan.
\end{abstract}


Siti Aminah

PENGEMBANGAN DESAIN MODEL PEMBELAJARAN BLENDED LEARNING ...

REFLEKSI EDUKATIKA : Jurnal Ilmiah Kependidikan, Volume 11, Nomor 1, Desember 2020, hlm. 8-15

\section{PENDAHULUAN}

Pembelajaran untuk mahasiswa Program Studi Teknik Informatika, khususnya yang berkaitan dengan mata kuliah matematika, khususnya Metode Numerik belum banyak dikembangkan. Oleh karena itu, perlu dikembangkan model pembelajaran matematika khusus mahasiswa program studi Teknik Informatika. Model pembelajaran matematika yang akan dikembangkan diharapkan dapat memotivasi semangat mahasiswa dan tertantang dalam belajar matematika.

Mahasiswa Teknik informatika kurang termotivasi dalam belajar matematika. Mereka sering mengeluhkan setelah mempelajari perhitungan yang rumit, perhitungan ini akan digunakan untuk apa. Mereka merasa tidak membutuhkan melakukan perhitungan matematika karena tidak berguna bagi keilmuan mereka sebagai mahasiswa Teknik informatika. Dari sini, penulis merasa perlu mengembangkan desain model pembelajaran agar pembelajaran matematika bermakna bagi mereka, khususnya mahasiswa Teknik Informatika.

Penggunaan elektronik di masa saat ini sangat beragam. Mahasiswa di masa sekarang tidak lepas dari barang elektronik, seperti gadget, laptop dan lain-lain. Semakin canggihnya Teknologi Informasi Komunikasi saat ini, sebaiknya dosen mengembangkan model pembelajaran mengikuti kebiasan mereka, yang tidak bisa lepas dari barang-barang elektronik dan internet. Model pembelajaran adalah tahapan terstruktur yang digunakan sebagai dasar untuk mencapai tujuan pembelajaran lengkap dengan bahan ajar yang digunakan (Affandi et al., 2013). Model pembelajaran yang memungkinkan di masa sekarang adalah online learning atau blended learning. Peneliti lebih memilih mengembangkan model pembelajaran blended learning karena menjaga interaksi dan komunikasi antar mahasiswa dan antara mahasiswa dan dosen dapat terus berlangsung (Wardani et al., 2018). Menurutnya, dalam mengembangkan pembelajaran blended learning perlu adanya strategi pengorganisasian pengajaran, penyampaian pengajaran, dan kualitas pengajaran yang tepat.

Peneliti mengembangkan desain pembelajaran blended learning pada mata kuliah metode numerik. Hal ini seperti yang dilakukan oleh Irwan \& Angraini (2019) yang mendeskripsikan desain pembelajaran blended learning pada perkuliahan hubungan internasional. Bedanya, penelitian ini adalah penelitian pengembangan yang mengacu pada Thiagarajan. Model pembelajaran akan dikembangkan oleh peneliti merupakan kombinasi dan modifikasi dari pembelajaran Two Stay Two Stray (TSTS) dan Project-Problem based Learning (PBL), yang selanjutnya oleh peneliti akan disebut Blended Cooperative Learning (BCL).

Rumusan masalah dari penelitian ini yaitu bagaimanakah mengembangkan model pembelajaran BCL sesuai tahapan Thiagaradjan? Tujuan dari penelitian ini yaitu untuk mengembangkan sintak pembelajaran dan bahan ajar yang digunakan pada model pembelajaran BCL sesuai dengan tahapan pada Thiagaradjan. Manfaat dari penelitian ini yakni sebagai referensi bagi pendidik lainnya dalam memilih model pembelajaran blended learning. Selain itu, model pembelajaran ini bisa menjadi alternatif pembelajaran blended learning bagi pendidik lainnya dalam mengajar.

Model pembelajaran BCL memiliki beberapa karakteristik, yaitu pembelajaran yang diberikan berbasis masalah dan proyek, dilakukan secara hybrid, dan mahasiswa bermain peran. Model BCL diharapkan menjadi alternatif pembelajaran bagi mahasiswa Teknik Informatika. Model ini disusun berdasarkan modifikasi dari Problem-Project based learning. Model pembelajaran Project-Problem based learning ini meliputi 4 kriteria, yaitu menuntun peserta didik menyelesaiakan masalah melalui pertanyaan, peserta didik menghubungkan masalah dengan bidangnya (pada penelitian ini adalah bidang Teknik Informatika), menggunakan proyek ilmiah, dan peserta didik terlibat dalam kelompok untuk menyelesaikan proyek (Nagarajan \& Overton, 2019). Output dari pembelajaran dengan menggunakan model BCL ini adalah aplikasi komputer dari masalah yang diberikan.

Model BCL ini menggunakan pendekatan dengan pembelajaran berbasis proyek, dimana pembelajaran berbasis proyek harus menghasilkan output berupa produk (Patton, 2012; Almujab, 2018; Pratiwi, Ardianti dan Kanzunnudin, 2018; Attalina, 2020; Kurniawan, 2020). Model BCL juga akan menghasilkan output berupa aplikasi program. Dengan begitu, mahasiswa yang dasarnya mereka telah belajar 
Siti Aminah

PENGEMBANGAN DESAIN MODEL PEMBELAJARAN BLENDED LEARNING ...

REFLEKSI EDUKATIKA : Jurnal Ilmiah Kependidikan, Volume 11, Nomor 1, Desember 2020, hlm. 8-15

bahasa pemograman, akan tertantang untuk menghasilkan aplikasi setelah pembelajaran.

BCL ini dimulai dengan belajar individu yang dilanjutkan berdiskusi dalam kelompok secara daring. Selanjutnya, peserta didik juga berdiskusi secara langsung di dalam kelas dengan teman-temannya. Pembelajaran seperti ini dinamakan blended learning. Blended learning adalah pembelajaran yang mengkombinasikan pembelajaran sinkronus dengan pembelajaran asinkronus dengan tujuan pembelajaran berjalan secara efektif (Chaeruman \& Maudiarti, 2018). Blended learning harus memiliki karakter terbuka, fleksibel, dan dapat terjadi dimana saja (Purnomo et al., 2016). Karena materi yang dipelajari cukup banyak dengan waktu yang terbatas, maka dibutuhkan waktu lebih lama untuk belajar sehingga dapat dilakukan di luar jam pembelajaran. Melalui pembelajaran daring, peserta didik dapat belajar kapanpun dan dimanapun (Rusman, Kurniawan \& Riyana, 2013)

Pada BCL ini juga terdapat aktifitas bermain peran, dan menjalankan perannya sebagai tamu dan tuan rumah seperti pada pembelajaran Two Stay Two Stray, yang selanjutnya disingkat dengan TSTS. TSTS adalah pembelajaran kooperatif yang hasil Tabel 1. Kriteria Valid

$\begin{array}{cc}\text { Interval } & \text { Kriteria Valid } \\ \mathbf{2} \leq \overline{V_{a}} \leq \mathbf{3} & \text { Valid } \\ \mathbf{1} \leq \overline{V_{a}}<2 & \text { Cukup Valid } \\ \mathbf{0} \leq \overline{V_{a}}<1 & \text { Tidak Valid }\end{array}$

diskusi kelompoknya dibagikan kepada teman lainnya dengan cara saling mengunjungi kelompok lain (Lapohea, 2014). Dengan aktifitas ini, setiap mahasiswa akan memahami materi dari semua kelompok. Dengan aktifitas ini, setiap mahasiswa akan memahami materi dari semua kelompok. Selain itu, dengan aktifitas ini, mahasiswa didorong untuk bersosialisasi dengan baik, bekerja sama, dan bertanggung jawab terhadap tugas individu maupun kelompok.

\section{METODE PENELITIAN}

Tahapan pada penelitian mengacu pada model pengembangan Thiagarajan. Semmel \& Semmel yang dibatasi pada 3 tahap, yaitu tahap pendefinisian, tahap perencanaan dan tahap pengembangan. Tahap selanjutnya adalah tahap penyebaran (Thiagarajan et al., 1974). Tahap penyebaran akan dibahas pada penelitian selanjutnya.

Tahap pendefinisian terdiri dari 5 langkah, yaitu front-end analysis, learner analysis, concept analysis, task analysis, dan specifying instructional objective. Pada tahap perancangan ada 4 langkah meliputi constructing criterion-referenced test, media selection, format selection, dan initial design.
Dan pada tahap pengembangan meliputi uji validasi dan uji pengembangan. Pada tahap pengembangan, dibatasi pada tahap uji validasi. Untuk Uji pengembangan akan dibahas pada penelitian selanjutnya.

Data yang digunakan pada penelitian ini yakni data kuantitatif dan data kualitatif. Data kuantitaif diperoleh dari hasil validasi pengembangan model BCL dan bahan ajarnya. Instrumen yang digunakan untuk pengumpulan data adalah lembar validasi RPP dengan pembelajaran BCL dan lembar validasi bahan ajar dengan pembelajaran BCL.
Teknik analisa data pada data hasil validasi dihitung menggunakan perhitungan ratarata dengan penggunaan kriteria kevalidan (Parta, 2009). Validasi dilakukan oleh 2 ahli Pendidikan dari segi aktifitas dalam pembelajaran, konten dalam bahan ajar dan konten dalam LMS. Data kualitatif berupa penjelasan proses pengembangan model BCL sesuai tahapan pengembangan Thiagarajan. Penelitian ini dilakukan pada mahasiswa STIKI Program Studi Teknik Informatika yang menempuh mata kuliah Metode Numerik pada tahun ajaran 2019/2020. 
Siti Aminah

PENGEMBANGAN DESAIN MODEL PEMBELAJARAN BLENDED LEARNING ... REFLEKSI EDUKATIKA : Jurnal Ilmiah Kependidikan, Volume 11, Nomor 1, Desember 2020, hlm. 8-15

\section{HASIL DAN PEMBAHASAN}

Tahapan pertama adalah tahap pendefinisian yang terdiri dari 5 langkah. Langkah pertama pada tahap pendefinisian adalah front-end analysis. Setelah dilakukan analisa dengan observasi maupun wawancara terhadap mahasiswa, mahasiswa merasa mata kuliah yang terkait dengan Teknik Informatika tidak penting bagi mereka, karena mereka merasa untuk membuat aplikasi komputer tidak harus bisa matematika. Namun mata kuliah Metode Numerik adalah mata kuliah wajib bagi mereka. Sehingga mereka kurang termotivasi untuk belajar matematika meski mereka mampu. Selain itu, terdapat beberapa mahasiswa yang menganggap matematika adalah sulit, sehingga saat pembelajaran mereka mengalami lambat dalam belajar matematika.

Langkah kedua pada tahap pendefinisian adalah learner analysis. Mahasiswa yang menempuh mata kuliah metode numerik berasal dari latar belakang sekolah menengah yang berbeda, yaitu SMA dan SMK segala jurusan. Sehingga pengetahuan awal yang dibutuhkan untuk mata kuliah metode numerik sangat berbeda.

Langkah ketiga pada tahap pendefinisian adalah concept analysis. Model BCL diterapkan pada materi sistem persamaan linier dan sistem persamaan nonlinier. Submateri pada sistem persamaan linier adalah penyelesaian sistem persamaan linier menggunakan metode eliminasi Gauss, eliminasi Gauss-Jordan, Invers matriks, Dekomposisi, Iterasi Jacobi, Iterasi Seidell dan Cramer. Sedangkan submateri pada sistem persamaan nonlinier adalah mencari salah satu akar dari sistem persamaan nonlinier dengan menggunakan metode bagi dua, posisi palsu, iterasi tetap, newton Raphson, dan secant.

Langkah keempat pada tahap pendefinisian adalah task analysis. Terdapat tiga model pembelajaran, yaitu competitive learning model, individual learning dan cooperative learning (Slavin, 1995). Tugas yang akan diberikan apda mahasiswa mengandung tiga macam pendekatan tersebut.

Langkah kelima pada tahap pendefinisian adalah Specifying Instructional Objective. Pada tahap ini disusun tujuan pembelajaran, yaitu mahasiswa mampu memahami dan menjelaskan metode penyelesaian menggunakan metode numerik, kemudian menerapkan konsep dan metode tersebut dengan membuat aplikasinya, dan melaporkannya.

Tahap kedua adalah tahap perencanaan, terdiri dari 4 langkah. Langkah pertama pada tahap perencanaan adalah The ConstructingReferenced Test. Tes yang disusun pada pembelajaran ini adalah pretes dan posttest.

Langkah kedua dari tahapan perencanaan adalah pemilihan media. Media yang digunakan adalah bahan ajar berupa Learning Management System (LMS) dan worksheet.

Langkah ketiga dari tahapan perencanaan adalah pemilihan format. Format yang digunakan pada LMS terdiri dari materi awal, pretest, forum diskusi, pengumpulan tugas, posttest, lengkap denngan instruksi pembelajaran. Pada forum diskusi menggunakan LMS bersifat 3 hal, yaitu (1) Separate grup, hanya bisa dilihat dan digunakan oleh anggota kelompoknya sendiri, (2) Question and Answer, mahasiswa bisa melihat postingan teman jika telah memberikan komentar, dan (3) dapat diakses setelah mengerjakan pretes dengan nilai yang memenuhi syarat. Pada worksheet telah tersedia masalah yang akan dikerjakan dan didiskusikan. Masalah yang disajikan pada problem based learning adalah mempunyai satu solusi, masalah dilakukan secara berkelompok, siswa memperoleh informasi melalui self directed, dan masalah yang disajikan dapat meningkatkan kemampuan pemecahan masalah (Farhan \& Retnawati, 2014). Pada model BCL, masalah tersaji dalam bahan ajar berupa worksheet. Terdapat 5 worksheet dalam satu kali pembelajaran. Kriteria masalah yang disiapkan pada BCL adalah (1) setiap kelompok mendapat masalah yang berbeda namun tingkat kesulitannya sama, (2) masalah yang disajikan lengkap dengan petunjuk penyelesaian secara runtut.

Langkah keempat pada tahap perencanaan adalah initial design. Beberapa hal yang harus disiapkan sebelum melakukan model BCL adalah menyiapkan LMS sesuai format diatas dan worksheet yang berisi masalah sesuai kriteria diatas. Model BCL ini terbagi menjadi 2 waktu yaitu pembelajaran asinkronus dan pembelajaran sinkronus. Langkah-langkah pembelajaran pada BCL pada Tabel 2. 
Siti Aminah

PENGEMBANGAN DESAIN MODEL PEMBELAJARAN BLENDED LEARNING ...

REFLEKSI EDUKATIKA : Jurnal Ilmiah Kependidikan, Volume 11, Nomor 1, Desember 2020, hlm. 8-15

Tabel 2. Langkah - langkah dalam Model BCL

\begin{tabular}{|c|c|}
\hline Tahapan & Aktifitas Mahasiswa \\
\hline \multicolumn{2}{|r|}{ Pembelajaran Asinkronus } \\
\hline Belajar mandiri & $\begin{array}{ll}- & \text { Mahasiswa membaca instruksi di LMS } \\
\text { - } & \text { Membaca materi } \\
& \text { Pretest }\end{array}$ \\
\hline $\begin{array}{l}\text { Berdiskusi dengan teman satu } \\
\text { kelompok }\end{array}$ & $\begin{array}{l}\text { - } \quad \text { Mahasiswa masuk dalam forum diskusi } \\
\text { - } \quad \text { Mahasiswa mempelajari materi secara individu } \\
\text { - } \quad \text { Mahasiswa memposting pendapat/jawabannya dalam forum diskusi } \\
\text { ansiski dengan saling membalas postingan di forum diskusi }\end{array}$ \\
\hline Laporan & - $\quad$ Mahasiswa melaporkan hasil diskusi melalui fitur assignment \\
\hline Konfirmasi & $\begin{array}{l}\text { Mahasiswa akan mendapat konfirmasi bahwa hasil diskusi sudah benar. } \\
\text { Dan mendapat saran jika hasil diskusi kurang tepat untuk direvisi }\end{array}$ \\
\hline \multicolumn{2}{|r|}{ Pembelajaran Sinkronus } \\
\hline \multicolumn{2}{|r|}{ Pembuka } \\
\hline Evaluasi & $\begin{array}{l}\text { - Mahasiswa bersama dosen mengevaluasi pembelajaran asinkronus } \\
\text { - Mahasiswa memahami penjelasan dosen tentang model pembelajaran yang } \\
\text { akan digunakan }\end{array}$ \\
\hline \multicolumn{2}{|r|}{ Kegiatan Inti } \\
\hline Bermain Peran & $\begin{array}{l}\text { Mahasiswa berbagi peran dengan kelompoknya, yaitu (1) Tuan Rumah } \\
\text { (cukup } 1 \text { orang dari tiap kelompok) bertugas menjelaskan penyelesaian } \\
\text { dari masalah yang telah disubmit pada saat pembelajaran asinkronus dan } \\
\text { (2) Tamu (sisa anggota lainnya), berbagi tugas untuk berkeliling ke } \\
\text { kelompok yang berbeda untuk memahami penjelasan dari penyelesaian } \\
\text { masalah kelompok lainnya. }\end{array}$ \\
\hline Kembali ke kelompok asal & $\begin{array}{l}\text { - Mahasiswa kembali ke kelompok, bergantian untuk menjelaskan materi } \\
\text { hasil bertamu }\end{array}$ \\
\hline \multicolumn{2}{|r|}{ Penutup } \\
\hline Kesimpulan & $\begin{array}{l}\text { - Mahasiswa bersama dosen menyimpulkan hasil pembelajaran asinkronus } \\
\text { dan sinkronus }\end{array}$ \\
\hline \multicolumn{2}{|r|}{ Pembelajaran Asinkronus } \\
\hline Proyek & Mahasiswa mengerjakan proyek dan dikumpulkan dalam fitur assignment \\
\hline
\end{tabular}

Pada pembelajaran asinkronus, dosen menggunakan learning management sytem (LMS). LMS yang dipilih peneliti adalah moodle, sesuai dengan LMS yang dipergunakan STIKI. Menurut (Al-Samarraie \& Saeed, 2018) pembelajaran menggunakan LMS memiliki banyak peluang seperti dapat menunjukkan contoh dengan cara yang terorganisir dengan baik, dapat memfasilitasi diskusi yang lebih dalam di antara para peserta didik, dapat didesain untuk belajar mandiri atau belajar kolaboratif, membantu rasa saling percaya dalam tim, pekerjaan dan aktifitas peserta didik tersimpan semua. Ini sesuai dengan sintak pembelajaran pada BCL dimana siswa diajak untuk belajar mandiri dan belajar berkelompok. Belajar berkelompok pada BCL disetting menjadi 2 macam, belajar dalam kelompok dimana hanya kelompok yang bisa mengakses, dan belajar dalam kelompok dimana semua mahasiswa dapat mengakses. Aktifitas seperti ini dapat dilakukan dalam LMS. Aktifitas ini disusun untuk tercapainya tujuan pembelajaran yaitu mahasiswa mampu memahami dan menjelaskan metode penyelesaian menggunakan metode numerik, kemudian menerapkan konsep dan metode tersebut dengan membuat aplikasinya, dan melaporkannya.

Aktifitas pertama yang dilakukan oleh mahasiswa dalam LMS adalah belajar mandiri. Belajar mandiri ini bertujuan untuk mengukur kemampuan awal mahasiswa dan pengetahuan yang diperlukan untuk memahami materi yang dipelajari. Tujuannya adalah untuk meningkatkan kemandirian belajar mahasiswa, sehingga selanjutnya dapat menumbuhkan motivasi belajar. Ini sesuai dengan temuan (Sutisna, 2016) yang menyatakan bahwa model pembelajaran blended learning dapat meningkatkan kemandirian belajar siswa dalam pendidikan kesetaraan paket C. (Sutisna, 2016) kemandirian belajar dapat menumbuhkan 
Siti Aminah

PENGEMBANGAN DESAIN MODEL PEMBELAJARAN BLENDED LEARNING ...

REFLEKSI EDUKATIKA : Jurnal Ilmiah Kependidikan, Volume 11, Nomor 1, Desember 2020, hlm. 8-15

motivasi belajar dan kreativitas, sehingga meningkatkan prestasi peserta didik. Penelitian yang dia lakukan dengan memanfaatkan Teknologi Komunikasi Informasi (TIK) berupa $\mathrm{CD}$ interaktif dan e-book. Belajar mandiri pada BCL ini menggunakan materi dan kuis yang tersaji pada LMS.

Aktifitas kedua adalah berdiskusi dengan teman satu kelompok dalam fitur forum di LMS. Pada forum ini disetting hanya anggota dalam 1 kelompok saja yang bisa mengakses. Tujuannya mahasiswa bisa berdiskusi tanpa harus bertemu langsung, mahasiswa dapat menyampaikan ideide, apa yang dipahami dan belum dipahami kepada teman sekelompok. Kegiatan berkelompok ini bisa dilakukan dengan menggunakan LMS sama halnya berkelompok dengan setting sinkronus. Antar mahasiswa dapat berkomunikasi dengan anggota kelompok tanpa harus bertemu, tanpa terbatas waktu dan tempat. Begitupun juga dengan fitur ini dapat menjaga komunikasi antar mahasiswa dan dosen melalui konfirmasi dosen terhadap kegiatan diskusi mahasiswa di forum. Selain itu, kegiatan ini dapat meningkatkan konsep diri mahasiswa. Ini sesuai dengan pernyataan (Al-Samarraie \& Saeed, 2018) bahwa fitur forum pada LMS dapat meningkatkan konsep diri mahasiswa dan meningkatkan minat untuk aktif dalam percakapan. Dari pengalaman belajar seperti ini mahasiswa dapat menegoisasi konsep yang sedang dibahas dalam kelompok.

Aktifitas selanjutnya adalah laporan dan konfirmasi dari dosen. Laporan ini berisi rangkuman hasil akhir dari diskusi. Laporan ini dituliskan dalam sebuah file dan diupload di fitur assignment. Laporan ini harus dikonfirmasi oleh dosen baik sudah benar atau salah. Laporan yang salah akan dikembalikan untuk direvisi. Laporan yang sudah benar akan disampaikan ke anggota kelompok lainnya melalui setting pembelajaran sinkronus.

Setting pembelajaran di minggu berikutnya adalah pembelajaran sinkronus. Dimulai dengan evaluasi dari pembelajaran asinkronus yang telah dilakukan. Dilanjutkan dengan aktifitas pembelajaran bermain peran sebagai tamu dan tuan rumah dan kembali ke ke kelompok asal. Kegiatan ini adalah modifikasi kegiatan pembelajaran TSTS. Jika pada TSTS 2 orang tinggal dan 2 orang lainnya bertamu. Jika pada BCL hanya 1 orang yang tinggal dan sisa anggota kelompok lainnya bertamu. Setiap mahasiswa bisa bertamu ke 1 hingga 3 kelompok lainnya. Dari kegiatan ini ditemukan bahwa aktifitas ini dapat meningkatkan rasa percaya diri mahasiswa. Mahasiswa dituntut memahami dan mengkomunikasikan ke teman. Ini sesuai dengan (Mayasari, 2015) yang menyatakan bahwa pembelajaran TSTS dapat meningkatkan komunikasi matematis dan motivasi peserta didik. (Andrianingsih \& Waluya, 2019) menyatakan bahwa dengan pembelajaran TSTS dapat mendeskripsikan kemampuan komunikasi matematis peserta didik dalam beberapa kategori, yaitu high, medium and low self-efficacy.

Tahapan ketiga adalah tahap pengembangan. Pada tahap pengembangan dilakukan validasi ke para ahli. Hasil validasi kepada kedua validator tersaji dalam Tabel 3

Tabel 3. Hasil Validasi

\begin{tabular}{|c|c|c|c|c|c|}
\hline \multirow{2}{*}{ Jenis Bahan Ajar } & \multicolumn{2}{|c|}{ Hasil Penilaian } & \multirow{2}{*}{$\begin{array}{l}\text { Rata- } \\
\text { Rata }\end{array}$} & \multirow{2}{*}{ Kriteria } & \multirow{2}{*}{ Revisi } \\
\hline & Validator 1 & Validator 2 & & & \\
\hline $\begin{array}{l}\text { Penilaian Sintak Pembelajaran } \\
\text { BCL dan RPP }\end{array}$ & 2.8 & 2.5 & 2.6 & Valid & - \\
\hline Penilaian LMS & 2.5 & 2.3 & 2.4 & Valid & Perlu revisi \\
\hline Penilaian Bahan Ajar BCL & 2.2 & 2.4 & 2.3 & Valid & Perlu Revisi \\
\hline
\end{tabular}

Dari Tabel 3, ketiga bahan ajar telah valid. Namun membutuhkan revisi pada instruksi LMS tentang bagaimana penilaian pada aktifitas mahasiswa pada LMS. Dan revisi pada bahan ajar BCL tentang instruksi dengan bahasa yang lebih komunikatif sehingga mudah dipahami mahasiswa Program Studi Teknik Informatika.
Revisi bahan ajar dilakukan sesuai saran dari validator.

\section{SIMPULAN}

Berdasarkan hasil pembahasan diatas dapat diambil kesimpulan bahwa pengembangan model melalui tahap pendefinisian, tahap perancangan, dan tahap pengembangan. Dari 
Siti Aminah

PENGEMBANGAN DESAIN MODEL PEMBELAJARAN BLENDED LEARNING ...

REFLEKSI EDUKATIKA : Jurnal Ilmiah Kependidikan, Volume 11, Nomor 1, Desember 2020, hlm. 8-15

tahapan yang telah dilalui, peneliti menghasilkan model BCL lengkap dengan bahan ajarnya. Bahan ajar yang dihasilkan dari model BCL ini adalah RPP, pembelajaran asinkronus dalam LMS, dan worksheet. Dari hasil validasi model BCL sudah layak digunakan dalam pembelajaran Metode Numerik untuk mahasiswa Teknik Informatika. Begitu juga dengan RPP, pembelajaran asinkronus dalam LMS, dan worksheet telah layak digunakan.

Harapannya, model BCL ini dapat diterapkan pada mata kuliah lainnya dengan beberapa penyesuaian. Penelitian ini didanai oleh Direktorat Jenderal Pembelajaran dan Kemahasiswan, Kementrian Riset, Teknologi dan Pendidikan Tinggi dalam program Bantuan Penerapan Inovasi Pembelajaran Khusus Di Perguruan Tinggi. Peneliti mengucapkan terima kasih kepada Direktorat Jenderal Pembelajaran dan Kemahasiswan, Kementrian Riset, Teknologi dan Pendidikan Tinggi dan Sekolah Tinggi Informatika \& Komputer Indonesia (STIKI) Malang yang telah mendukung pelaksanaan penelitian ini.

\section{DAFTAR PUSTAKA}

Affandi, Muhammad, et al. 2013. Model dan Metode Pembelajaran di Sekolah. Semarang: Unissula Press.

Almujab, Saiful., et al. 2018. Penerapan Lesson Study Melalui Metode Project Based Learning Untuk Meningkatkan Keaktifan Mahasiswa Dalam Proses Pembelajaran Di FKIP UNPAS. REFLEKSI EDUKATIKA : Jurnal Ilmiah Kependidikan, 8 (2): 139-148.

Al-Samarraie, H., \& Saeed, N. 2018. A systematic review of cloud computing tools for collaborative learning: Opportunities and challenges to the blended-learning environment. Computers and Education, 124, 77-91. https://doi.org/10.1016/j.compedu.2018.0 5.016

Andrianingsih, V., \& Waluya, S. B. 2019. Mathematical Communication Ability Assessed by Student Self- efficacy in Learning the Two Stay Two Stray (TSTS) Model on Ability of Process Approach.
Unnes Journal of Mathematics Education Research, 10 (2): 140-146.

Attalina, Syailin Nichla Choirin. 2020. Penerapan Model Pembelajaran "Project Based Learning" Pada Mata Kuliah Pembelajaran Pendidikan Kewarganegaraan Sekolah Dasar DI UNISNU Jepara. REFLEKSI EDUKATIKA : Jurnal Ilmiah Kependidikan, 10 (2): 267-274.

Chaeruman, U. A., \& Maudiarti, S. 2018. Quadrant of Blended Learning: a Proposed Conceptual Model for Designing Effective Blended Learning. Jurnal Pembelajaran Inovatif, 1(1), 1-5. https://doi.org/10.21009/jpi.011.01

Farhan, M., dam Retnawati, H. 2014. Keefektifan PBL dan IBL Ditinjau dari Prestasi Belajar. Jurnal Riset Pendidikan Matematika, 1(2), 227-240.

Irwan, dan Angraini, M. T. R. 2019. Desain Model Pembelajaran Blended Learning Pada Perkuliahan Hubungan Internasional. REFLEKSI EDUKATIKA : Jurnal Ilmiah Kependidikan, 10 (1), 4857.

Kurniawan, Rahmat. 2020. Pengembangan Model Pembelajaran Guided Project Basedlearning Untuk Mahasiswa Slowlearner. REFLEKSI EDUKATIKA : Jurnal Ilmiah Kependidikan, 10 (2): 144153

Lapohea, A. Z. 2014. Penerapan Model Pembelajaran Kooperatif Tipe Two Stay Two Stray untuk Meningkatkan Hasil Belajar Siswa pada Materi Logika Matematika. Jurnal Elektronik Pendidikan Matematika Tadulako, 1(2): 133-145.

http://download.portalgaruda.org/article.p hp? article $=276789 \&$ val $=5148$

Mayasari, D. 2015. Penerapan Model Pembelajaran Two Stay Two Stray untuk Meningkatkan Komunikasi Matematis dan Motivasi Siswa. Prosiding Seminar Nasional Matematika Dan Pendidikan 
Siti Aminah

PENGEMBANGAN DESAIN MODEL PEMBELAJARAN BLENDED LEARNING ...

REFLEKSI EDUKATIKA : Jurnal Ilmiah Kependidikan, Volume 11, Nomor 1, Desember 2020, hlm. 8-15

Matematika, 102-111.

Nagarajan, S., \& Overton, T. 2019. Promoting Systems Thinking Using Project- And Problem-Based Learning. Journal of Chemical Education. https://doi.org/10.1021/acs.jchemed.9b00 358

Parta, I. N. 2009. Pengembangan Model Pembelajaran Inquiry untuk Penghalusan Pengetahuan Matematika Mahasiswa Calon Guru melalui Pengajuan Pertanyaan. (Tesis). Surabaya: Universitas Negeri Surabaya.

Patton, A. 2012. Work that matters: the teacher's guide for project based learning. The Hamlyn Foundation.

Pratiwi, Ika Ari., Ardianti, Sekar Dwi., dan Kanzunnudin, Moh. 2018. Peningkatan Kemampuan Kerjasama Melalui Model Project Based Learning (PJBL) Berbantuan Metode Edutainment pada Mata Pelajaran Ilmu Pengetahuan Sosial. REFLEKSI EDUKATIKA : Jurnal Ilmiah Kependidikan, 8(2): 177-182.
Rusman, Kurniawan, D., \& Riyana, C. 2013. Pembelajaran Berbasis Teknologi Informasi dan Komunikasi: Mengembangkan Profesionalitas Guru. Rajawali Pers.

Slavin, R. E. 1995. Cooperative Learning Theory, Research and Practise. Allymand $\&$ Bacon.

Sutisna, A. 2016. Pengembangan Model Pembelajaran Blended Learning pada Pendidikan Kesetaraan Program Paket C dalam Meningkatkan Kemandirian Belajar. JTP - Jurnal Teknologi Pendidikan, $18 \quad$ (3): 156-168. https://doi.org/10.21009/jtp1803.2

Thiagarajan, S. Semmel, D. ., \& Semmel, M. . 1974. Instructional Development for Training Teacher of Exceptional Children.

Wardani, D. N., Toenlioe, A. J. E., dan Wedi, A. 2018. Daya Tarik Pembelajaran Di Era 21 Dengan Blended Learning. Jurnal Kajian Teknologi Pendidikan (JKTP), 1 (1): 1318. 